\title{
THE CALIFORNIA GOLD RUSH
}




\section{BY JOHN WALTON CAUGHEY}

\section{HISTORY OF THE PACIFIC COAST}

BERNARDO DE GALVEZ IN LOUISIANA

MCGILLIVRAY OF THE CREEKS

CALIFORNIA

HUBERT HOWE BANCROFT, HISTORIAN OF THE WEST THE CALIFORNIA GOLD RUSH (GOLD IS THE CORNERSTONE)

AMERICA SINCE 1763

IN CLEAR AND PRESENT DANGER:

THE CRUCIAL STATE OF OUR FREEDOMS

A HISTORY OF THE UNITED STATES (with Ernest R. May)

LAND OF THE FREE (with John Hope Franklin and Ernest R. May)

SCHOOL SEGREGATION ON OUR DOORSTEP (with LaRee Caughey)

THE PUEBLO WATER RIGHT OF LOS ANGELES

HISTORICALLY CONSIDERED

THE AMERICAN WEST

TO KILL A CHILD'S SPIRIT:

THE TRAGEDY OF SCHOOL SEGREGATION IN LOS ANGELES

\section{EDITED BY JOHN WALTON CAUGHEY}

THE EMIGRANTS' GUIDE TO CALIFORNIA

By Joseph E. Ware

THE LOS ANGELES STAR, 1851-1864

By William B. Rice

RUSHING FOR GOLD

ROBERT OWEN, SOCIAL IDEALIST

By Rowland Hill Harvey

EAST FLORIDA, 1783-1785, A FILE OF DOCUMENTS

By Joseph Byrne Lockey

THE INDIANS OF SOUTHERN CALIFORNIA IN 1852:

THE B. D. WILSON REPORT

SEEING THE ELEPHANT:

LETTERS OF R. R. TAYLOR, FORTY-NINER

SIX MONTHS IN THE GOLD MINES

By E. Gould Buffum

THEIR MAJESTIES THE MOB

CALIFORNIA HERITAGE:

AN ANTHOLOGY OF HISTORY AND LITERATURE

(with LaRee Caughey) 


\section{THE CALIFORNIA GOLD RUSH}

\section{JOHN WALTON CAUGHEY}

$W$ ith vignettes by $W . R$. Cameron

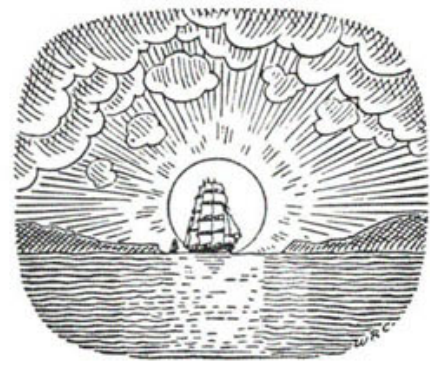

UNIVERSITY OF CALIFORNIA PRESS

Berkeley, Los Angeles, London 
UNIVERSITY OF CALIFORNIA PRESS

BERKELEY AND LOS ANGELES

CALIFORNIA

UNIVERSITY OF CALIFORNLA PRESS, LTD.

LONDON, ENGLAND

COPYRIGHT, 1948, BY

THE REGENTS OF THE UNIVERSITY OF CALIFORNIA

PAPERBACK EDITION, 1975

ISBN: $0-520-02763-9$

THIS BOOK WAS ORIGINALLY PUBLISHED IN THE CHRONICLES OF CALIFORNIA UNDER THE TITLE Gold is the Cornerstone.

PRINTED IN THE UNITED STATES OF AMERICA 
To

ELMER BELT

WHO ONCE DID

SOME PROSPECTING

ON MY ACCOUNT 
